\title{
Icelandic genomics firm goes bankrupt
}

\author{
deCODE's demise leaves fate of its valuable genetic database unclear.
}

After struggling financially for years, the genomics company deCODE, based in Reykjavik, Iceland, filed for bankruptcy on 16 November. The question now is whether other companies looking to commercialize genomics will follow the same path.

Scientists are already lamenting the prospect of losing deCODE's vast database of genetic and medical information, which includes much of Iceland's population (see graphic). "There is no researcher doing genetics who would not want access to a certain amount of those data," says Manolis Dermitzakis, a geneticist at the University of Geneva Medical School in Switzerland. "It would be a huge loss if the data disappear."

Analysts blame business decisions and a mountain of debt for bringing deCODE down. The worldwide financial crisis also played a part; US\$30 million of deCODE's money was managed by Lehman Brothers before Lehman's collapse. But deCODE's chief executive, Kári Stefánsson, says other factors were more important. "The Icelandic economy is in a bad shape, but that is not the reason why we are where we are," he says. "We probably founded the company a few years too early."

deCODE was founded in 1996 to find the genetic roots of common diseases such as schizophrenia, heart disease and cancer, and was wildly successful at this task. "deCODE has carried out many seminal studies, which any medical school would have been proud to see published," says David Goldstein, a geneticist at Duke University in Durham, North Carolina.

But the business of turning genetic discoveries into cash has long been difficult, and many such firms have converted themselves into drug-discovery operations. Unfortunately for deCODE, it could not develop drugs quickly enough to satisfy investors. Stefánsson says that

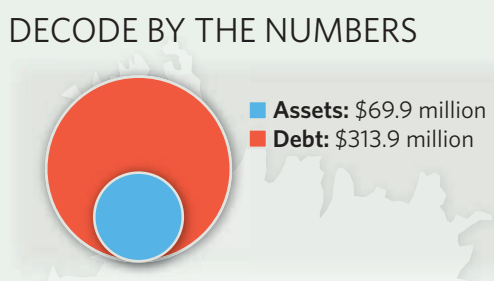

Proposed sale price: \$14 million

Icelanders represented in its database: 140,000 Research publications: 102

Diagnostic scans marketed: 6

Drugs marketed: 0

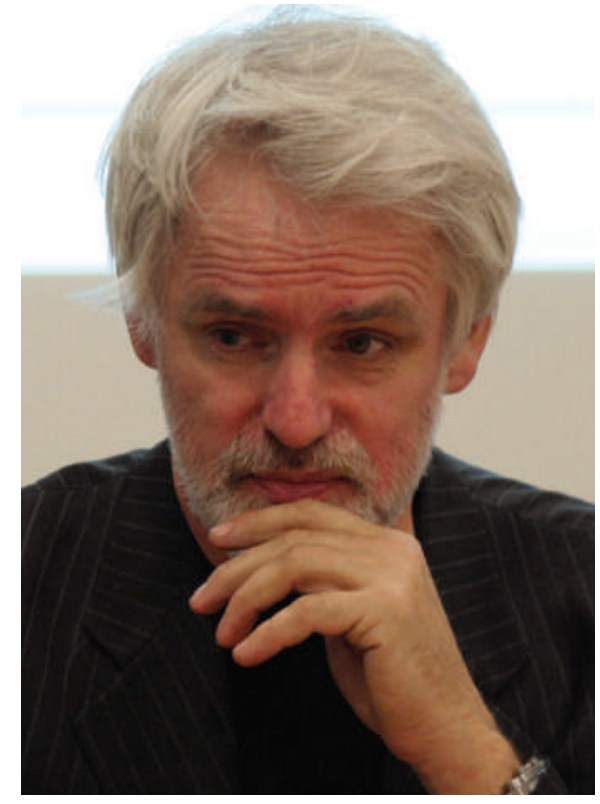

Kári Stefánsson led a major genetic database.

may be because it began its work before cheap, standardized technologies for genome analysis, such as single nucleotide polymorphism (SNP) chips, became widely available.

Some other researchers, however, say that deCODE's scientific approach is to blame. The company worked to mine genetic data for common variations linked to disease through genome-wide association studies (GWAS), and some experts note that these studies have turned up only a small fraction of the variation that causes disease.

"The translation to commercial value is just not very direct," says Goldstein, "in part because it is now clear that GWAS is not the tool of choice for unlocking the genetics of most common diseases."

Stefánsson and others disagree. "Five years ago there was no direct evidence that GWAS studies would provide us with completely new genes or pathways causing disease, and now there are close to 200 findings replicated," says Leena Peltonen, head of human genetics at the Wellcome Trust Sanger Institute, near Cambridge, UK. Stefánsson points to deCODE products such as a cardiovascular test that can detect a nearly twofold increase in the risk of heart attack.

And other companies are beginning to make inroads in drug development guided by genetics. Human Genome Sciences of Rockville, Maryland, transformed itself into a drugdiscovery company some years ago after failing to convince other companies to subscribe to its genetic database. This year, the company announced the completion of promising clinical trials for a drug to treat the autoimmune disease lupus.

Many companies are vying to create and own genetic content in different ways, "so in the long run I don't think [deCODE's] problems are systemic", says Isaac Ro, an analyst at Leerink Swann in New York.

But companies that focus exclusively on personal genomics services, such as the one sold by deCODE as deCODEme, might find themselves in more trouble, Ro says. The services are not seen as a medical necessity, diminishing their appeal, particularly in difficult economic times. This year the personal-genomics company 23andMe, based in Mountain View, California, announced two rounds of lay-offs, lost one of its two co-founders and announced a series of product and price restructurings.

"There's no clinical trial supporting the value of these results, so it's really recreational genomics," Ro says. Large academic centres, not consumers, will find value in the rich genetic databases; 23 andMe has tried to move into the research market, but because its data come from a self-selected customer population their value is limited, he says.

By contrast, deCODE's database incorporates a wide range of valuable information coupled with biological samples.

CODE intends to sell most of its assets, including its drug-discovery and development services and the unit that conducts its genetic research, to Saga Investments, a US venturecapital-backed company, unless a better offer is made. The database and biological samples themselves cannot be sold, Stefánsson says, because of legal restrictions on their use. He says that the Wellcome Trust in Britain had approached deCODE to try to fund a nonprofit institute to manage the database in Iceland, but was unable to do so.

"The database will never be managed by a foreign organization," he says. "The data are sensitive. We are a proud nation, and the data are not for others to manage."

Erika Check Hayden 